JEASP

Journal of English for Academic and Specific Purposes

Volume 4 Number 1, June, 2021

\title{
ENGAGING STUDENTS IN ONLINE READING GAMES: A STUDENT-CENTERED
} LEARNING PERSPECTIVE

\author{
Prima Purbasari ${ }^{1}$ \\ (purbasariprima@gmail.com) \\ Iffatunnida, ${ }^{2}$ \\ (nidaiffatun89@gmail.com) \\ Urwatus Silvia Rahmah ${ }^{3}$ \\ (viasilviara13@gmail.com)
}

Pusat Pengembangan Bahasa Inggris

Universitas Islam Negeri Maulana Malik Ibrahim Malang ${ }^{123}$

\begin{abstract}
ARTICLE
Keywords:

online games

Reading skill

student-centered learning

ABSTRACT

2020 might be unforgettable for teachers since they need to face the challenging teaching situation in the ruinous Covid-19 pandemic. To deliver the lesson, teachers need varied online applications to reach their students. Furthermore, they need more online media to ensure the students grasp what they need to achieve as a learning outcome. Online games are used in this study as the supportive learning tool after lecturing session about Reading Strategies. Furthermore, it is the tool to engage students to practice the student-centered learning so that they will be autonomous learners. There are four games used in this study i.e. Main Idea Millionaire, Main Idea Storm, Context Clues, and Scanning \& Skimming games, which are provided in three different websites. This is a qualitative phenomenological study expecting to capture details and experience of students and then to describe the meaning of the findings based on the subjects' individual experience. The study was conducted in Universitas Islam Negeri Maulana Malik Ibrahim Malang, exactly at Architectural Engineering Department. Based on the findings, students thought that online reading games helped them to visualize the context of particular texts because of its good animation and sound effects. Students, in teacher's evaluation, became more active in engaging themselves in the class discussion after having several activities of playing the online reading games. They said that they could easily play the games over and over anytime. This study proves that the employed online games can boost students' confidence and encourage them to be active in the teaching and learning situation.
\end{abstract}

\section{INTRODUCTION}

Teachers all over the world are now in-touch with technology thanks to the Covid-19 pandemic. The no-other-options situation escalates technology literacy among educators almost equally and reduces the excuse 
JEASP

Journal of English for Academic and Specific Purposes

Volume 4 Number 1, June, 2021

of not wanting to use technology as the teaching-learning media. The number of applications and websites supporting online learning are getting greater these days as educators kindly suggest others to use it. Whilst adults may not be willing to employ computers at home or in their work place, the use of gadgets, internet, and various multimedia platforms are natural for children and youth. Recently with the emergence of new computerized and net-based technologies such as the internet, learners have unlimited access to online games. Learners can easily connect to the internet and sign into specific kinds of net games in order to participate actively in interactive games. This is why schools should employ them as often as possible to increase their learners' achievement (Sütheő, 2004).

The use of technology has been considered effective for self-learning where students independently select what they want to learn inside or outside the classroom (Liu, 2016). Their chance to freely use the gadget (mainly mobile phone) during online learning is expected to gain two things at once i.e. achievement and joy of learning. The learning place that has completely changed during the pandemic is supposed to give students freedom to design the comfortable place and nuance during the online class. They can surely join the class while staying in their bedroom or any other places they are in as long as they do not ignore the flow of the class activities.

The major role of applying technology is to encourage students to participate and to engage them in the class activities. In the process, it is possible to reach a boredom climax in doing online class both for the teacher and students. Although students can now fully use their favorite gadget for learning experience, they eventually reach the point in which they realize that online classrooms have limitations. They have no direct interaction with their classmates nor chance to have face-to-face consultation with their teacher. They basically only receive the learning material, try to understand it, then they will be tested if they have already comprehended it. This repetitive cycle goes on and on that makes it possible to trigger lack of interest in following the next online class. At this time, the teacher needs to provide a way out so that the students can stay focused and raise students' interest on what they are learning at the moment.

One of the ways is playing games. Usually, in the traditional foreign language classroom, students will play games as an ice-breaking in the middle of the learning process. In discussing things like employing games within language learning, most studies found in scientific journals have young learners as their research objects (Wang, 2010; Yolageldili \& Arikan, 2011; Bakhsh, 2016). Whereas, not only young learners that need games in the learning activities, but the adult learners or university students do too. This is caused by the fact that games support learning experience (Cam \& Tran, 2017). It helps students to focus more on the learning target in a game situation. During the game, students feel less tense when making mistakes, especially in using the target language. The use of games in education plays an important role in engaging students by encouraging a hands on approach (Zirawaga et. al., 2017). In this pandemic situation where in-class games are impossible, the teacher definitely needs the online ones since students also currently spend much time in online activities and it is mostly on games.

Regarding this, online games should not be randomly chosen without evading the learning goal in certain meetings. It is expected that the games can help students to understand the lesson better instead of only 
JEASP

Journal of English for Academic and Specific Purposes

Volume 4 Number 1, June, 2021

functioning as the intermezzo in between the activities. In line with this, several things need to be confirmed by the teachers before deciding the online games for the learning experience. These include the platform for online games that must be accessible for all students and it should not require too much internet data.

Online games are usually made by international game companies targeting global users; thus, the main language used in the application is English. So, students can make use of their hobby in playing online games to elevate their English skills. The thing is, there are still few studies exploring online activities, particularly online games, for additional out-of-class learning opportunities. Hence, students have yet to put interest in combining their leisure and learning activities through online games (Jeon, 2014: 88). Studies need to be conducted to guide teachers to exploit the use of online games in creating the effective learning experience, mainly for the after-class activities.

The ultimate aim of using the advanced technology in class activities is to assist students to be independent learners. This aim is targeted to fulfill the institution's aspiration to create the autonomous learning nuance that aims at students' needs and goals (Brown \& Lee, 2015). This is crucially needed because students are now driven to be able to help their own selves in learning. The online class with teacher's assistance is used as the confirmation of what they have already understood during the independent learning.

There are several previous studies implementing online games in their reading activities. However, they mainly focus on the improvement of students' grammar comprehension (Tuan \& Doan, 2010; Yolageldili \& Arikan, 2011; Lawrence \& Lawrence, 2013; Cam \& Tran, 2017) and vocabulary (Bakhsh, 2016). Thus, the major purpose of the current study is to explore the effects of online games, after selecting the games provided in several websites, on student-centered learning experience as they are learning to understand English texts comprehensively and implement the reading skills that have been conveyed by the lecturer in the online class. In addition, their opinions and feelings concerning the way they learn about certain reading strategies through online games will also be a great measurement.

As educators and researchers have been trying to create several teaching and learning methods while aiming for certain objectives, one of which is the learning outcome, several factors need to be taken into consideration. Those include a good atmosphere or learning environment as has been stated by Kasvi (2000) who has listed the seven requirements for an effective learning environment as taken from the information proposed by Norman (1993). These requirements comprise the needs to provide a high intensity of interaction and feedback, create specific objectives and procedures, become motivational, offer a persistent feeling of challenge so that it will not be too difficult to cause frustration nor too easy to cause boredom, create a sense of feeling attached to the task given, give the right tools to complete the task, and prevent any disturbance and interferences that can ruin the experience. Hence, Kasvi (2000) believes that games, particularly online games, meet all these requirements to achieve the goals of teaching and learning.

It is necessary to get to the fundamental understanding that reading is the process of comprehending print and graphic text or finding out the meaning of texts. As mentioned in the book created by the Ministry of Education of Ontario (2004), writers have employed many ways to convey the meaning of words and various concepts, both the overt and subtle ones. Therefore, readers should know that the text they read must be logical. 
JEASP

Journal of English for Academic and Specific Purposes

Volume 4 Number 1, June, 2021

Effective readers will monitor their understanding and unconsciously choose and apply a reading strategy when they cannot grasp the meaning of what they are reading. One reading strategy that can be a solution to reconnect the meaning of the text is context clues or using the context of a text to find the meaning of certain words. It can help students to guess the meaning of the vocabularies, which they meet when reading texts that are unfamiliar to them. These so-called clues may be examples, comparison, parenthetical notes, elaboration, definitions, illustrations, clarifications or descriptions.

A different type of reading strategy that cannot be neglected is a pair called skimming and scanning. They are usually implemented interchangeably but for different purposes. These speed reading techniques can be said as inseparable from reading comprehension skills. Skimming is reading texts quickly to find out the main idea and, sometimes, some details of the paragraphs. Skimming allows the readers to read fast in order to get the general meaning of the paragraphs when finding particular information. This way, they can make a decision whether they want to continue reading more intensely or leaving the paragraphs because they cannot find the information they need. For using this technique, the readers should read the first paragraphs, two or more middle paragraphs, and the last paragraph to be able to have a basic understanding of the topic. People frequently read the topic sentence and concluding sentence only since the readers are not necessarily required to read and understand every word. Pictures, diagrams or charts can be taken as parts of the skimming activity. The other one, scanning, is reading texts quickly to search for specific details. When the readers need to find only a fact, name, date, or certain word in a text without having to know about the details, then scanning is preferable. The steps are instigated by making a prediction about where in the text they might be able to find the information. They also need to notice whether the paragraphs are arranged based on the order of time, place, logical idea, or event to make the job easier. While moving their eyes vertically or diagonally, they should keep looking for the associated words that may lead them to the detailed information they need.

\section{Applying Games in A World of Education}

In this era, it is undeniable that games are inseparable from the learning process since children are used to playing games while learning, and adults are no exceptions. It is in accordance with the argument stated by Gee (2005) who believes that games are understood as conceptual models working across formal and informal learning contexts in language teaching and learning processes. In language teaching, according to Warschauer and Healey (1998, as cited in Sørensen \& Meyer, 2007), games have often been utilized to increase motivation and authentic communicative practices, since games have been conceptualized as an enjoyable factor in language learning. They create a fun environment in which learners and even the teacher become more interested in the learning and teaching process.

Gaming is a key activity in students' off school practices and most interactive games provide learners with communicative activities as they play games. Thus, the game players will be using the language and accordingly learn it in order to participate in games (Sørensen\& Meyer 2007). Interactivity in gaming acts as communication patterns in conversation, consultation, transmission and registration. These understandings partly are compatible with the communicative and socio-cognitive approaches to language and language learning, 
JEASP

Journal of English for Academic and Specific Purposes

Volume 4 Number 1, June, 2021

i.e. the prioritization of negotiation and communicative ability, which is supported by Warschauer and Kern (2000), and Warschauer and Healey (1998). In off school contexts, according to Sørensen \& Audon (2004), and Warschauer (2004), children usually understand and utilize languages as a communicative tool, gathering information and gaming, whereas in schools, the understanding and use of languages is often understood to be the purpose of doing the tasks.

Wu, Yen, and Marek (2011) investigated the effects of online EFL interaction on confidence, motivation, and ability suggesting enjoyment as a key factor in increasing these learning variables. Any type of communication in the target language or with the target culture, used in the online games in which students get to read the English instruction to complete the quest about certain reading topics and strategies, will ultimately improve their English proficiency level as well as their interest and motivation in reading.

Ke (2009) in the study entitled "a qualitative meta-analysis of computer games as learning tools" concluded that the most effective models or practices of designing and utilizing instructional gaming would be resulted by carefully regulating and integrating the three clusters of critical variables such as learning, learner, and instructional game design. Computer games are also a motivating and interactive means of assisting young learners in improving their English vocabulary (Vasileiadou \& Marina, 2017). In addition, Sanchez et. al. (2007) suggested the introduction of games should be attractive in order to get students' interest and to achieve the goals. Teachers should take into consideration some factors like deciding on which game to utilize and the allotted time (Yolageldili \& Arikan 2011). It is also confirmed by Yip and Kwan (2006) that information about designing an effective lesson plan and skills required for incorporating online elements into teaching and learning processes are deemed necessary to become effective facilitators.

Further, motivation is a key concept in many theories of learning. Katzeff (2000) stresses motivation is a critical factor for instructional design, and the learner must be motivated to learn. Malone and Lepper (1987) present a theoretical framework of intrinsic motivation in the design of educational computer games. They postulate that intrinsic motivation is created by four individual factors: challenge, fantasy, curiosity and control and three interpersonal factors: cooperation, competition and recognition. Interestingly many of these factors also describe what makes a good game, irrespective of its educational qualities. Hence, to point out the connection between online games and English reading class, it is essential to refer to Orey (2010) who argues that educators need to understand the existential intelligence. Likewise, he provides the information that the linguistics area concerns writing and reading. The crucial skills that should be acquired by the learners to be able to understand reading texts comprehensively and having the ability to write well can be obtained through hearing and seeing words, speaking, reading, writing, discussing, and debating. In association with this theory, online games may be a good option for the learners to be engaged in since the learners will absolutely encounter the needs to listen to, see, read, and write the answers for the online games given by the instructors, teachers or lecturers as a task.

Online games-based learning that is implemented in English classes, especially for reading comprehension skill is considered as one of the communication types in the teaching and learning process. It is known as computer mediated communication bringing a great change in the way educators (tutors, teachers or 
JEASP

Journal of English for Academic and Specific Purposes

Volume 4 Number 1, June, 2021

lecturers) and students think about teaching and learning activities. Permitting students to study in other places other than schools or universities, which may be more convenient for them. It also makes a lifelong learning process possible. (Kassop, 2003). In the midst of this epidemic disease, computers or other gadgets are surely the educators' and learners' must-have items for conducting the teaching and learning activities, for traditional classroom activities are impossible to be conducted. Thus, assigning students to play online games whenever they want and they need without setting a time duration or schedules will provide them a chance to have a lifelong learning education. Moreover, this type of communication deforms the power and authority relationships between the educators and learners. The traditional hierarchy is trampled, while authority and control are restructured more equally and openly than how it usually occurs in conventional educational settings (Schrum \& Hong, 2002). This subsequently leads to student-centered learning in which the focus of learning is diverted from the educators or teacher (teacher-centered) to the learners or students. Unconsciously, students learned the materials or lesson by themselves. Of course they are still assisted by the teachers or lecturers but with minimum interference.

\section{Main Idea Millionaire Game}

This is one of the four games used in this study based on the aforementioned Reading Strategies materials. It is provided in www.roomrecess.com focusing on Main Idea. Students can choose whether they want to use a mouse or touchscreen for playing this game. They will see the instructions after choosing one of the buttons. Those are three icons that signify three different actions; the "New" icon means that the player can get an entirely new problem, the "Remove" icon means that players may remove one incorrect answer, and the "50/50" icon allows players to show one correct answer and one incorrect answer. Afterward, clicking the "go" button will lead the players to the game where they can see 14 levels and various amounts of money as the prize for passing each level, of course they will not be given real money. The first level starts with the lowest amount of money that is 100 dollars. The prizes then will get bigger as the players advance towards the higher levels, and the final prize is one million dollars, which will be obtained as they pass the final level successfully. The mission is finding one sentence that does not belong to the story, which does not support the main idea of the story.

\section{Main Idea-Storm Game}

The second game is featured in the same website as the first game that is www.roomrecess.com. Starting the game, the players are told to read the short story written in the storm cloud. Then, they have to look at the three trees below the storm cloud and find the main idea. There is also information that the players should send down the lightning to the correct main idea written in the tree by swiping down the storm cloud. On the top left of the screen, the players can see the notification telling them about the numbers of correct and wrong answers as well as the grade written in alphabet (A, B, C, D, E or F). The game expects the players to identify the correct main idea of each story so that they can progress beyond simple fluency and begin to read for understanding. 
JEASP

Journal of English for Academic and Specific Purposes

Volume 4 Number 1, June, 2021

\section{Context Clues Game}

For practicing the skill of figuring out the meaning of new vocabularies the students meet when reading certain English texts, they are assigned to play the game provided by www.education.com. It is a vocabulary quiz concerning context clues. Through the game, students will test their knowledge of context clues. They will be given sentences, and they can also listen to the spoken sentence through the audio. Next, they must choose one of the four synonyms to replace the mentioned word. There are only three questions provided, but the students can click the "next" button if they want to challenge themselves with the next game about vocabularies and synonyms. Here, they are asked to move the given words to the correct columns containing words that have similar meanings Since identifying synonyms is an important part of a reading and writing curriculum, strengthening vocabulary can help students to determine meaning using context clues.

\section{Scanning and Skimming Game}

Through the game created by www.educaplay.com, students can practice their skill in scanning and skimming for the needed information delivered in English texts. They have to skim and scan the information of the picture attached in the game and answer the questions correctly. On the screen, they can see the time duration, 5 minutes. As the players, they are also warned about sensitive issues that may affect the answers, such as upper or lower case and accents. Once they click the "start" button, they will see a text and a question next to it. The option to zoom in the text is also available if they want to read the paragraphs better. In five minutes, they have to answer five questions. After completing the game, they can see their successful rate right away, see the correct answers, or play the game again. It is also possible for them to create a challenge in which they can compete against their friends to see who gets the best score in the activity, but to do so, they must log in or sign up.

\section{Student-Centered Learning as A Meaningful Experience}

Students, nowadays, are no longer the receiver in the learning context. They are not deemed to be a mere object of learning for they need to be the 'main actor' in this field. The basic principle of studentcenteredness is that students get their freedom to choose what they want to study. However, it does not mean that they can learn everything without guidance. Students will first set their learning outcome depending on the prior knowledge given by their teacher before independently searching for the way to gain what has been targeted. Student-Centered Learning (SCL) approach focuses on students as the subject who is expected to be active and autonomous. They are hoped so because they are considered as adult learners that are already able to make their own decision, as well as have concerns on why and how they should learn. This approach then leads to many different terms such as flexible learning, experiential learning and self-directed learning. No wonder does the SCL have dissimilar meaning for various people who try defining it (O’Neill \& McMahon, 2005: 31).

SCL was first introduced to offer the shift learning environment paradigm where usually teachers dominate the learning process. In the mentioned approach, the learning emphasizes on students rather than the teachers. Students' active participation and impression are the ones that should be given the big portion of focus 
JEASP

Journal of English for Academic and Specific Purposes

Volume 4 Number 1, June, 2021

because it is believed to bring more live and passionate atmosphere. It is designed so to match the learning outcome of each subject in educational institutions - that is to make students more knowledgeable by experiencing a meaningful learning process.

From various literatures discussing SCL, Lea et al. (2003) highlight several essential points on this approach. First, it emphasizes active rather than passive learning. Since students are deemed to be autonomous for what they want to study, the approach allows them to show how far they can be active in the learning process. It is no longer about teachers transferring the science - from the expert to the novice - but more on what students can do. Second, SCL underlines deep learning and understanding. When students are provided more chances to show their capability, they autonomously will search for what they need to learn. This unconsciously will be the internal motivation to gain much more knowledge through their learning experience. During the process, they will definitely encounter the unclear material. They can both ask the teacher or do independent search for more explanation - here we know that SCL places teachers as facilitators rather than the dominant role of a learning process. These acts demonstrate students' responsibility as 'knowledge hunter' i.e. to be au fait with what they need to know.

Third, SCL points up the interdependence between teacher and learner. We cannot call it a teachinglearning process if the dominant part is only on either teacher or student. This approach builds effective two-way communication between teacher and students. Teacher, as an educator, needs students to be active in the class activities so that the ELO (Expected Learning Outcome) of the study can be achieved. Likewise, students need their teacher to guide them in their autonomous learning process. Teachers certainly cannot expect their students to be $100 \%$ independent since they need to confirm one or more things so that they acquire meaningful knowledge. This interdependence of both parties eventually guides to the mutual respect within their relationship (Lea et al., 2003).

In a further discussion, O’Neill and McMahon (2005: 34) elucidate possible SCL activities which are practical for teaching-learning experience.

Table 2.1. Examples of student centered learning/teaching method

(O’Neill \& McMahon, 2005)

\begin{tabular}{ll}
\multicolumn{1}{c}{ During the lecture } & Outside the lecturing process \\
\hline Short discussion in pair & Independent project \\
$\begin{array}{l}\text { Cross-overs (mixing students into groups by letter/number } \\
\text { allocations) }\end{array}$ & Peer mentoring of other students \\
Rounds (giving turns to individual students to talk) & Debates \\
& Reflective diaries, learning journals
\end{tabular}




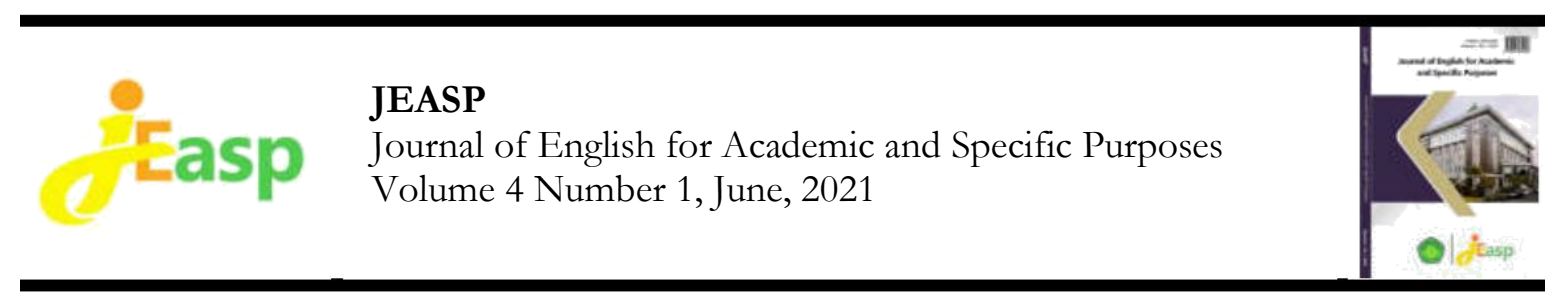

Students producing mind maps in class

Quizzes

Role play
Writing newspaper article

Field trips

Computer assisted learning

As shown in the table above, SCL gives a broad chance for students and teachers to fill in their respective roles and no single party overpowers another one. Students are expected to resume their learning experience after the class; meanwhile, teachers are obliged to give a formative assessment in the form of giving feedback to the students on their learning process.

\section{Previous Studies}

There are a number of research studies conducted in EFL (English as a Foreign Language) classes that employ games in the teaching-learning process. Yolageldili and Arikan (2011) explore the use of games in EFL class when teaching grammar to the young learners. Before starting, the teacher definitely told them what grammar lesson they should focus on. So, in the middle of playing the games, students can direct their attention and check if they have already mastered the lesson. They gain pleasure when gaming and at the same time they are also able to achieve the new language skills. The thing highlighted by these researchers is that game acts as the media where teachers can adjust to suit learners' age and language level. The games providing colorful and presentable pictures will attract the young learners' attention more. It does not mean that adult learners such as university students will be already satisfied with games which only have texts without interesting decoration whatsoever. They surely will love it when the games have many things to see. Another finding of the aforementioned study points out that games involve equal participation from both slow and fast learners. Furthermore, they add that games can be applied in any language teaching situations and it is also not limited to only one skill.

Another researcher also implements games-based teaching to young learners. They are elementary students who learn English in Saudi Arabia. Here, the researcher who is also a teacher employs five games in his class; they are Hot Potatoes, Memory Challenge, Last One Standing, Pictionary, and Bingo (Bakhsh, 2016). This selection is done because the teacher wants the students to move around the class during the game activities. He agrees to the statement that young learners are not supposed to sit for a long time when learning since they can easily lose focus.

Because of its pleasurable and fun situation, several researchers found that games are very much applicable in a class of adult learners as well. Tuan and Doan (2010) do an in-depth discussion to prove the effectiveness of online games in teaching English grammar. They say that there are still many teachers employing games for grammar teaching, yet the games are manual i.e. using handouts and pictures without considering the use of technology. To change this mindset, they then emphasize that the technology involved in the learning process eases the teacher's role. It facilitates the needs of modern learning and saves teacher's time and effort. Its use attracts students and benefits those who are not assured of showing their English skills in front of the class. 
JEASP

Journal of English for Academic and Specific Purposes

Volume 4 Number 1, June, 2021

Warschauer (1996) and Brinton (2001) express, with the help of computer and internet, teachers and students are served with unlimited resources which can be used as materials required in the learning process. For teachers, especially, the World Wide Web (WWW) supplies tremendous authentic media materials that show students the connection between the language classroom and other parts of the world.

Cam and Tran (2017) also conduct a study focusing on the employment of games in English class. Their research participants are freshmen of English major in Dong Nai Technology University, Vietnam taking Grammar class twice a week. Beside the desire to find the benefits of games in learning English, this study also wants to explore students' thoughts about English grammar, whether they think it is important or not. The result shows that $44 \%$ of students affirm the beneficial effects of games when learning English grammar. They say that through games, they understand the lesson about grammar better than the mere explanation in the class and that they are delighted the teacher decided to use games in the class. The experience of participating in grammarfocused games gives enjoyment to students and it helps them learn quicker. However, students also find that it is boring if games are employed over and over. Therefore, the researchers combine the games with other learning approaches such as Grammar Translation Method (GTM), Communicative Language Teaching (CLT), and/or Task-Based Language Teaching (TBLT). This combination of different approaches then is proven to be effective because it assists students to apprehend the learning content and supports them to practice English in a real daily situation.

To sum up, those research studies did employ games in the EFL classrooms to help students improve their English skills. However, the first two studies emphasized the employment of games for young learners who are in the ages of elementary students. The result of both studies cannot be used for the improvement of adult learners since there should be different characteristics in the learning behavior. There are also studies about online games in EFL conducted at university level, which can be used for current researchers. However, all previous studies focused on the learning of grammar and vocabulary thus the games selection is also suitable for both classes. No other skills are assessed there.

In this recent study, the researchers specify the online games for university students. It is done so that the result will not only be beneficial for the betterment of adult learners, but also, generally, for the development of EFL teaching activities in the universities. Eluding the broad discussion, this study will only use online games for the quality improvement of students' reading skill. Thus, the selected games and materials included within the games will concern more on Reading Skill discussion. Furthermore, this study assesses if there is a connection of online games usage with student-centered learning.

\section{METHOD}

The research design of this study is a qualitative phenomenological approach on engaging students' activities in online reading games related to students centered learning perspective. A phenomenology is an approach to qualitative research that describes the meaning of lived experience of a phenomenon of several individuals. Students were selected from one specific curriculum and guidelines of students' learning achievement, which helped to maintain the homogeneity of the sample. Purposive criterion sampling was used to 


\section{JEASP}

Journal of English for Academic and Specific Purposes

Volume 4 Number 1, June, 2021

identify students who have experienced the phenomenon of reading classroom through online reading games as one of the tools during online learning. 30 students of $\mathrm{C}$ class majoring in the Architectural Engineering Department enrolled in the Science and Technology Faculty at Universitas Islam Negeri Maulana Malik Ibrahim, Malang, East Java, were selected to be the subjects in this study. Although there is no standard for a minimum number of participants in qualitative research because its purpose is not to generalize.

For this research, the materials that were going to be chosen and used were online reading games that involved and taught students about reading strategies like Main Idea ( https://www.roomrecess.com/mobile/MainIdeaMillionaire/play.html https://www.roomrecess.com/mobile/MainIdea/play.html), Scanning and Skimming (https://www.educaplay.com/learning-resources/2690075-skimming_and_scanning.html), and Context Clues (https://www.education.com/ game/vocabulary-context-clues-quiz/). All these games were selected because they lent themselves well to simple online interactive activity requiring reading comprehension skills, such as identifying main ideas, skimming - scanning, and recognizing context clues, which give them new experiences and interactive learning.

The instruments were developed by the researchers. In order to get basic knowledge about students' activities in online reading games based on a student-centered learning perspective, the researchers used students reading logs as the first instrument to examine students' activities in online reading games and describe the experiences while they access the reading online games. The Motivation for Reading Questionnaire (MRQ) by Wigfield and Guthrie (1997) assess different aspects of reading motivation.

Blueprint Motivations for reading questionnaire (MRQ), Wigfield and Guthrie (1997)

\begin{tabular}{ll} 
Reading Efficacy & - I don't know that I will do well in reading next year \\
- I am a good reader & - I learn more from reading than most students in the class \\
\hline Reading Challenge & - I like hard, challenging books \\
- If the project is interesting, I can read difficult materials & - I like it when the questions in books make me think \\
- I usually learn difficult things by reading & - If a book is interesting I don't care how hard it is to read
\end{tabular}

Reading Curiosity

- If the teacher discusses something interesting I might read more about it

- I have favorite subjects that I like to read about

- I read to learn new information about topics that interest me

- I read about my hobbies to learn more about them

- I like to read about new things

- I enjoy reading books about living things

Reading Involvement

- I read stories about fantasy and make believe

- I like mysteries

- I make pictures in my mind when I read

- I feel like I make friends with people in good books 


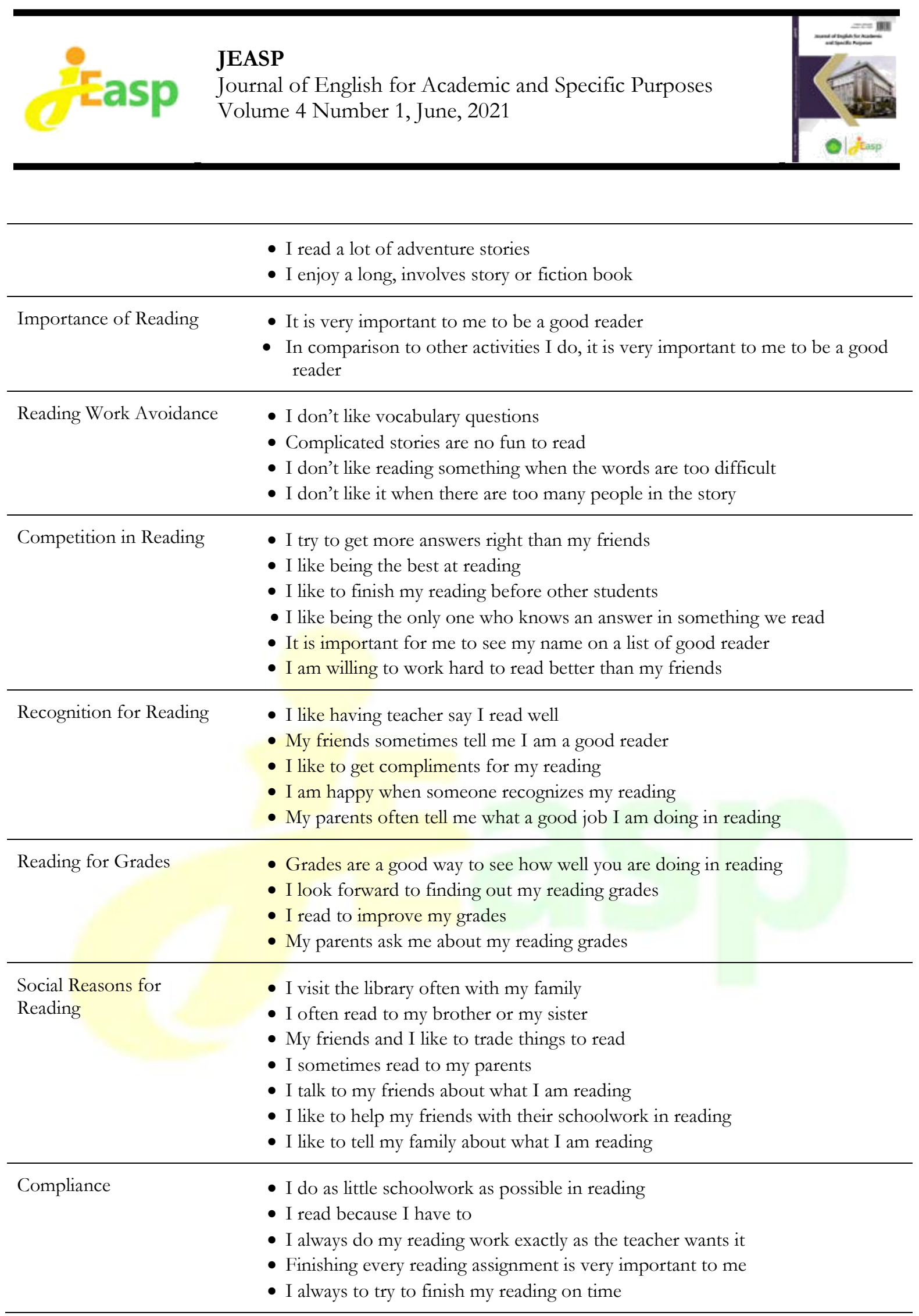

Since this research tries to know the students' centered learning perspective on online reading games activities, the researchers focus only on some aspects provided by MRQ. Those are reading challenge, reading curiosity, reading for grades, importance of reading, and reading involvement that play roles as the basis of students' reading log on their reading experiences. 


\section{JEASP}

Journal of English for Academic and Specific Purposes

Volume 4 Number 1, June, 2021

The last instrument was students' interviews. This instrument was used to know students' perspective and reasons related to reading activity through online games. The interview questions containing the frameworks of students centered learning perspective and the aspects of motivation for reading were developed.

Blueprint Student-Centered Learning Framework TEAL (Teaching Excellence in Adult Literacy) Center (2010: $1-2)$

Learners:

- Are active participants in their own learning.

- Make decisions about what and how they will learn.

- Construct new knowledge and skills by building on current knowledge and skills.

- Understand expectations and are encouraged to use self-assessment measures.

- Monitor their own learning to develop strategies for learning.

- Work in collaboration with other learners.

- Produce work that demonstrates authentic learning.

Instructors:

- Recognize and accommodate different learning modalities.

- Provide structure without being overly directive.

- Listen to and respect each learner's point of view.

- Encourage and facilitate learners' shared decision-making.

- Help learners work through difficulties by asking open-ended questions to help them arrive at conclusions or solutions that are satisfactory to them.

Learning is:

- An active search for meaning by the learner.

- Constructing knowledge rather than passively receiving it----shaping as well as being shaped by experiences.

Instructional strategies and methods are used to:

- Manage time in flexible ways to match learner needs.

- Include learning activities that are personally relevant to learners.

- Give learners increasing responsibility for the learning process.

- Provide questions and tasks that stimulate learners' thinking beyond rote memorization.

- Help learners refine their understanding by using critical thinking skills.

- Support learners in developing and using effective learning strategies for each task.

- Include peer learning and peer teaching as part of the instructional method.

The researchers only adapted some points of four aspects of the student-centered learning perspective by TEAL which were to know and analyze the results of students' interviews. Those were students' participation, reading performances, learning modalities, decision making, reading for meaning, constructing knowledge, managing time, responsibility, and learning strategies. As the data sources, there are two types of data that the researcher tried to obtain in the present study. The first was derived from students reading logs on their experiences accessing the online reading games. The last data was the result of an interview session about students' centered learning perspective and motivation for reading related to reading activity through online games.

In order to collect the data, the researchers provided students' reading log and interviews related to their experiences in motivation for reading to be matched with students' activities in online reading games by 
JEASP

Journal of English for Academic and Specific Purposes

Volume 4 Number 1, June, 2021

their perspectives. After all processes of the data collection were completed, the data analysis was done through some steps. The results of the students reading log were obtained by checking the list of aspects of reading motivation on reading activities through online games. After checking, the researchers categorized the list based on the same aspect of reading motivation with an overview comprising broad descriptive observation. The last step was analyzing the interviews session concerning students' perspective and reasons related to reading activity through online games. For the last stage, after interpreting the data, the researchers then interpreted the results of observation which led them to draw the conclusion for their research about engaging students' activities in online reading games based on the students-centered learning perspective.

\section{FINDINGS AND DISCUSSION}

\section{Findings}

Based on the interview guides employed to obtain information from the students, as the object of the research, the findings are explicated in four different categories. Those are the learners', instructors', learning, and instructional strategy or method aspects. Regarding the question or issue about their active participation during the discussion held by the lecturer, they acknowledged that they feel much more active than the previous weeks because they learned more about several topics through playing the reading games shared by the lecturer. While some of them are quite active, half of the class members are very active.

The subsequent finding, focusing on the learners' aspect, is about grade and the way students respond to grade, which is used to measure how well they are doing in reading comprehension. The students think that there are absolutely no other ways to know the quality of their understanding except scoring. They got used to receiving scores or grades and comment or feedback, given by the lecturer. Consequently, grading is a good tool or measurement to also check their improvement in understanding English text. However, a big number of students also opine that they should also be evaluated based on their performance in the class or their active participation during the class activities to make the assessment fair.

Seen from the instructors' aspect, many of the students said that the learning media used by the lecturer are quite challenging because the lecturer used various learning media, including the online reading games. Thus, they needed to learn not only about how to operate them but also how to get the best understanding of the English text provided there. However, they enjoy these types of activities because there is no way that they will feel bored with the class activities. They can set their choice on any online reading games they are fond of.

Moving on to the following aspect that is the learning aspect, the students have the same understanding that reading is an active search for understanding the meaning. They think that they can get to know more about vocabularies through reading because they used online dictionaries to check the meaning of specific terms. A few of them even implemented the context clues strategy to know the meaning since they have learned about it through online games. Indeed, they argue that reading can literally construct their knowledge skill. Reading about interesting topics, according to the students who have different tastes in reading topics, can help them refine 
JEASP

Journal of English for Academic and Specific Purposes

Volume 4 Number 1, June, 2021

their reading skills; one of them is the main idea. They also became aware of other elements of paragraphs when they were asked to identify particular elements in paragraphs.

Last of all, regarding the instructional strategy or method aspect, all students agree that they are able to manage their time in flexible ways and match the games with their reading needs. Since these Architectural Engineering students got many tasks to do from other lecturers who are teaching other subjects, they can hardly manage their time to play the games. However, the rules stating that there is no specific schedule about when they must play the games have put them at ease. They can play the games at the most convenient time for them. Being unaware of the fact, the student then finally realized that their responsibility for the learning process is also increased after playing the online reading games although only a few of them. They felt that they are held responsible for the learning process by playing the online reading games. These students automatically become aware of the "task" given to them to learn more about certain topics by themselves. The way they study about the topics given and refine their reading skills, specifically identifying the explicit and implicit main idea of particular reading texts, bring them to light that these skills are essential for their performance in the English class. The better they understand these, the better the chance to get the hang of it and become cleverer.

There are only a few students state that the online reading games could not help them to understand the materials, such as main idea, context clues and skimming and scanning strategies. They prefer to have a direct or a face-to-face meeting because they opine that, that way, they can gain a better understanding. Thus, the whole online class is not their best choice. A bigger number of students argued that online reading games are interesting because they love playing, but they don't think they get a better understanding regarding the materials they have to learn. So, they need to do some other exercises given by the lecturer to practice the reading strategies. In contrast, the majority of the class members definitely loved the online reading games and thought of them as the effective learning strategies for doing their task. They can play while studying, and, without realizing it, they have gained more information about the materials. They also learned about how to implement the reading strategies, so their reading skills have been quite enhanced. They can confidently make this statement because they were able to identify the parts of the reading texts and answered the questions delivered by the lecturer correctly on the next meetings.

From 30 students, 21 of them chose to play Main Idea Millionaire game. Four of them play this game because they think it's similar to the game that they usually watched on TV. It makes them curious to play the game, and it makes them reminisce about the old TV show. Although six students do not specifically mention the reasons why they feel that the game is interesting, six different students felt they were challenged by the game because the game only provides 3 chances to reach the higher levels. However, they can have another try if they fail to reach the higher or final level. Thus, all of these students say that they play the game more than once because they want to challenge themselves and get to the highest level. While five students just state that they play the game to develop their skill in identifying the main idea and understand paragraph coherence, someone considers this game as an exercise to enhance his vocabularies, and the other two just express that they feel the joy of getting online money. 
JEASP

Journal of English for Academic and Specific Purposes

Volume 4 Number 1, June, 2021

The game, according to the students' opinion, is indeed helpful since they can study the main idea while having fun. A number of students say that the game makes them focus on each sentence written in a paragraph, and they understand that they should be careful in creating a paragraph. Through this game, students learn that a good paragraph must have a good connection, meaning that every sentence written in the paragraph should be well connected to each other. This way, some say, they will know what the writer means. What is quite distinctive compared to the general responses, a minority of students think that the game helps them to increase their accuracy in reading and find out that high accuracy in reading a text is important.

The other online game is Main Idea-Storm Online Game. Students play this game because of the graphic or animation and great sound it has. They think this game is unique and cute because lightning will appear every time they choose the wrong answers although some students think that the sound is a little bit annoying. Initially, they only want to study more about the main idea by playing the game shared by the lecturer, but they feel happier that they can also play while studying. They realize that this game can help them learn English in different ways; also, they can play it during their spare time. Some think that the game is obviously simple and fun. Apparently, this game is not totally a new one for a few of them and they play it again with excitement because they want to see their improvement compared to the last attempt they made. Beside these popular responses, a few admit that the game is useful for them for learning new vocabularies or just remembering some vocabularies that they have forgotten because they rarely read English texts nowadays. Right after choosing the wrong answer, they are immediately given the right answer, so they learn better and can enhance their vocabulary bank as well as improve their reading skill.

The students learn more about identifying and determining the correct main idea for sure since they need to focus on the content of the paragraphs in a short time. Some state that the game is not too hard, and the choice of words used in the game is easy to understand. At last, some students learned that being patient and accurate when reading something to figure out the main idea of the text are necessary.

The third one is Context Clues Online Game, which is totally loved by the students. They say that it is fun, short, has no time limit, and can help them increase their knowledge about vocabularies. They claim that they know more about synonyms. The audio, from which the students can hear the spoken version of the sentences, can also help them learn more about pronunciation. Yet, another student thinks that the game's concept is less interesting. The last game selected is Scanning and Skimming Online Game. Through the game created by educaplay.com, students can practice their skill in scanning and skimming for the needed information delivered in English texts. They have to skim and scan the information of the picture attached in the game and answer the questions correctly. On the screen, they can see the time duration, 5 minutes. Once they click the "start" button, they will see a text and a question next to it. The option to zoom in the text is also available if they want to read the paragraphs better. In five minutes, they have to answer five questions. After completing the game, they can see their successful rate right away, see the correct answers, or play the game again. It is also possible for them to create a challenge in which they can compete against their friends to see who gets the best score in the activity, but to do so, they must log in or sign up. 
JEASP

Journal of English for Academic and Specific Purposes

Volume 4 Number 1, June, 2021

The students are eager to play this game because they can play the game more than once, and most of them want to get a better or even a perfect score, so they play the game for more than once. Furthermore, of course, they do want to practice about scanning and skimming since the lecturer sometimes makes them compete against each other to answer the set questions about particular paragraphs during the class meeting. Again, what comes to their mind is the need to be patient and accurate when reading something. A minority of these students opine that they tend to get lazy during the reading activities, but the text provided in the game is not too long, so it is not that hard for them to play. Yet, the game is informative, and they can look for the correct answer at the end of the game. On the other hand, two people dislike the game because of the technical problem he encountered during playing the game, the PC problem, and because of the timer. He thinks the time constraint distracts him from playing well.

Some students admit that they now know how to apply speed reading strategy well because they are trained to give the required information in a limited time. They learn to adjust the focus, use the time effectively, be patient when they want to know what the text is about, and understand how to skim a text without missing single information. In addition, they gain some insights, such as reading the question ahead before reading the text, become unconsciously informed about the topic of the reading text given in the game, and reading the text quickly yet thoroughly. The only complaints they have are the small font used in the game and the limited numbers of questions it gives.

\section{DISCUSSION}

\section{The Selected Online Reading Games and Students' Perceptions Toward Reading Activity and Student-Centered Learning}

Indeed, the current pandemic situation has driven teachers to explore and implement the effective teaching and learning strategies and good online learning platforms. In relation to this, online reading game is positively one of the great preferences for online teaching and learning activities. It is effective to help the students to develop themselves to be effective readers who are capable of monitoring their understanding and use a reading strategy properly when dealing with English reading texts in effective ways. The researchers focus only on three reading skills to help students enhance their reading skills in order to get a profound understanding of the English reading texts they read.

The referred reading strategies are related to main ideas, context clues and reading comprehensions involving speed reading strategies named scanning and skimming, and online reading games that applied these reading strategies are provided by some websites for free. As already specified in the research findings section, those websites are www.roomrecess.com that provides two different games about identifying the explicit and 
JEASP

Hesla Journal of English for Academic and Specific Purposes

Volume 4 Number 1, June, 2021

implicit main ideas of some texts, www.education.com that creates a game about context clues, and www.educaplay.com that enables students to play a game related to skimming and scanning.

In order to acquire the basic knowledge concerning the students' activities in online reading games, student reading log used as the instrument of this research is the crucial document to examine students' activities in online reading games. The log also reflected the elements of motivation for reading which emphasized on the students' reading experiences on the aspects of challenge, curiosity, importance of reading, and their involvement while playing the online reading games. Thus, the researchers adapted the reading instruments called Motivations for Reading Questionnaire (MRQ) from Wigfield and Guthrie (1997) as the students' reading measurement. Referring to reading texts, educators have known that these texts are not only produced and found in books, articles or magazines, but these can also be accessed through some digital or online platforms like online reading games. These online reading games are part of educational games that are solely created to facilitate students to learn and develop their reading skills independently since reading skills are inseparable from learning activity.

In regard to the prior information about $\mathrm{MRQ}$, clear connections and significance between the reading instruments and students' perception should be shown. As conveyed in the preceding paragraph, four aspects were chosen among eleven aspects attached to reading motivations. The elements of the reading curiosity and involvement aspects can be seen from the students' opinions that the reading texts presented in the online reading games have triggered them to imagine the situation or context of particular texts given in the games. The animation and sounds that are designed in the online reading games have also played a role in constructing the visualization of the story written in the reading texts. Additionally, the importance of reading aspect has also obviously been disclosed the acknowledgement that it is important to be a good reader. They expressed that increasing their accuracy in reading is critical. Through the games about main idea, for instance, they can focus on each sentence written in a paragraph and understand that they should be careful in creating a paragraph. They learn that a good paragraph must have a good connection, meaning that every sentence written in the paragraph should be well connected to each other. This way, they will figure out the writers' messages.

Overall, after observing the perspective of the students majoring in the Architectural Engineering department of the Science and Technology faculty at Universitas Islam Negeri Maulana Malik Ibrahim Malang, concerning the online reading games used in the English class activities, it is fair to say that the results are decent. Based on the interview that was conducted with the students and the researchers' observation, the students become more active in engaging themselves in the class discussion after having several experiences of playing the online reading games assigned by the lecturer. It reflects how studying while playing, which can be executed at the most convenient time for them, helps them to understand the related materials better. Hence, it boosts their confidence to participate in the class discussion. This inference is supported by the arguments of the majority of the students who think of the online reading games as the effective learning strategies although a few of them have a contrastive argument because they still need the classic lecturing activity.

Referring to the blueprint of student-centered learning adapted from student-centered learning framework by TEAL (Teaching Excellence in Adult Literacy) Center (2010: 1-2), an accountable measure needs to be made by linking the aforesaid four aspects with the student-centered learning perspective. The aspects are 
JEASP

Journal of English for Academic and Specific Purposes

Volume 4 Number 1, June, 2021

the learners', instructors', learning, and instructional strategy or method aspects. The students' behaviors towards online reading games, their experiences, and their whole performances in the class meetings that involve reading activity are the keys to answer the research problems. Students should know their own expectations and are engrossed to use self-assessment measures. Giving the chance to play online reading games raises the students' awareness about the essentials to learn more about the topics since they must have a better understanding of certain topics if they want to obtain better scores in the game. As expressed by the students, almost all of them feel the urge to challenge themselves to achieve the highest levels of the games they choose to play because the games creators also provide the features to compete with other players worldwide.

Hence, they can also monitor their learning progress by playing the games constantly and check their current ranking. To accomplish certain levels of the games, of course they cannot be ignorant and ought to develop the learning strategies of their own to keep pace with other players. Next, what follows after a series of learning activities is the evaluation or assessment to find out the students' improvement and their learning outcomes. Regarding this matter, some of them express their opinion that they should not be evaluated merely based on the scores they successfully gained, but also their performance in the class. A simple grading will not fit for this situation.

The next one is the instructors' aspect that encompasses two elements. The first one involves a challenging learning media to accommodate the students' reading activity. It was affirmed by the students that the learning media used by the lecturers, which also play the role as the researchers, are quite challenging because the lecturers used various learning media, which is the online reading game. Thus, the students needed to learn not only about how to play the games, but also how to get a good understanding of the English text that they read to accomplish the mission of the online reading games. The second one, as proposed by TEAL Center (2010: 1-2), is about how educators ought to encourage and facilitate the learners' shared decision-making. In this case, the lecturers have absolutely encouraged the students to make decisions by their own concerning the reading activity. Here, the educators respect each learner's point of view. They were allowed to play any online reading games that attracted their attention.

Concerning the learning, the students firmly stated that reading texts support their efforts to get to know more about vocabularies for they used online dictionaries to check the meaning of specific terms and applied the context clues strategy since they have learned about it through online games. In short, they have constructed their knowledge about main idea, context clues and speed reading actively. As for the last aspect, the instructional strategy or method aspect, the students did think that the online reading games manage their time in flexible ways and they were able to match the online reading games with their reading needs. They can definitely play the games at the most convenient time for them. Thus, they are able to select and determine which learning activities or online reading games that are personally relevant to them.

Further, leading the discussion to the responsibility for the learning process. These students automatically become aware of the "task" given to them to study independently. They realized that they need to have a good performance in the class, so, they must learn more about certain topics by themselves to refine their reading skills, such as identifying the explicit and implicit main idea of particular reading texts. The majority of 
JEASP

Journal of English for Academic and Specific Purposes

Volume 4 Number 1, June, 2021

the class members definitely valued the online reading games and thought of them as the effective learning strategies. They could play while studying, and gained more information about the materials unconsciously.

\section{Online Reading games, Reading Comprehension Skills, and Student-Centered Learning}

Since the students are also exposed to several reading texts shown in the online reading games, discussing the connection between reading activity and the online games is essential. First of all, talking about the students' past experiences that involve reading activity is crucial. It is almost obvious that most students, who learn English as a foreign language, will not read English texts unless they are told to read particular texts. Only those who have a great interest in English subject and are highly motivated to get better over time that possibly read English texts for pleasure or academic reasons without being forced. Consequently, most of their decision for selecting the online reading games that have different reading texts is affected by the lecturer because, indeed, they have a little interest on English texts. This issue is also what drives the lecturer to look for other alternatives for encouraging students to read more and expose them to reading texts in fun ways. A variety of learning media, including online reading games, is employed to overcome this problem.

Through what Orey (2010) states, that educators need to understand the existential intelligence and pass it on to their students, a connection can be seen between online reading game and reading activity. For the intelligence area, specifically the linguistics area concerning writing and reading, the types of activities that can be performed to shape the students' existential intelligence are writing, reading, telling stories, talking, memorizing, or working at solving puzzles. In association with this theory, online games may be a good option for the students to be engaged in since students will absolutely encounter the needs to listen to, see, read, and write the answers in the online games.

By focusing on the basic principle of student-centeredness, which is letting students get their freedom to choose what they want to study, using the online reading games as a part of the teaching and learning activity is then totally on track. If educators want to implement the student-centered learning approach in their class, they need to refrain themselves from giving too many commands to the students and ask them to study particular topics without considering their voices. Adjusting to the current situation, educators certainly need to take this type of teaching approach into account since they cannot really monitor and control their students' performances during the class activities in the real time and all the time. This is due to many external factors, such as the internet connection, the students' economic condition, and other factors that can possibly inhibit the teaching and learning process. Automatically, if they feel the importance of the student-centered learning approach, they need to change the focus of the learning. It should be diverted from the educators or teacher (teacher-centered) to the learners or students.

Assigning students to play online reading games to learn specific topics for reading comprehension in the English class is indeed a good alternative among other several options. Then, again, handing the students the right to choose what they want to play and study is accordingly the right step to take because these university students are considered as adult learners that are already able to make their own decision. They also certainly have concerns on why and how they should learn about certain topics; in this case, those are the reading 
JEASP

Journal of English for Academic and Specific Purposes

Volume 4 Number 1, June, 2021

strategies. Educators have to give more experiential learning for the students so that they can figure out what learning style that is most suitable for them. Students' active participation and impression are the ones that should be given the big portion of focus because it is believed to bring a more live and passionate atmosphere. It is proven by their enthusiasm that was recorded through the interview and students' log that were employed as the instrument for collecting the data and gaining relevant information for the research.

Most of them feel happy about the rules of learning that are assessing the web for playing the game at any time convenient to them, getting the right to choose any game they want to play, and playing the game as much as they want. The students' log, which was filled up by the students right after they play certain games, show their enthusiasm for the games. The most loved one is the online game about the main idea that can be accessed through the web "roomrecess.com." This game is played 36 times, which points out that six people have played this game twice. It instantly demonstrates students' responsibility as the 'knowledge hunter', another highlight of the student-centered approach. On the other hand, it is different from other online reading games that received less attention as these games were only played for 22 times (main idea millionaire \& skimming and scanning) and 25 times (context clues). The results indicate that a number of students, from 30 students in total, did not attempt to play these three games.

Furthermore, having the authority to choose what they want to study through the online game and play the games by themselves means that the students are engaged in an active rather than a passive learning. Other crucial points in the student-centered learning approach are deep learning and understanding. Without previously being taught about paragraph coherence, as shown through the students' log and interview, the students obtained some insight that they should be careful in creating a paragraph, and a good paragraph must have a good connection. So, as what they expressed, every sentence written in the paragraph should be well connected to each other. From another game about main idea, they also learned that being patient and accurate when reading something to figure out the main idea of the text are necessary. They are also able to enrich their vocabularies and their knowledge about synonyms through the game that illustrates the use of context clues, which is another crucial strategy in reading comprehension. Last, but not least, the game reflecting skimming and scanning strategies have successfully brought them into a new level of awareness and understanding. They learn to adjust the focus, use the time effectively, be patient when they want to know what the text is about, and understand how to skim a text without missing single information.

Moreover, leaning towards the student centered learning or teaching method proposed by O’Neill \& McMahon (2005), the aforementioned descriptions indicate that reflective diaries and learning journals that can be used for the teaching and learning tools outside the lecturing process are effective. These help the lecturer to monitor the students' progress as well as maintaining mutual respect between the lecturer and the students. This, connecting to the theory made by Kassop (2003) concerning online games-based learning, also makes a lifelong learning process possible. It is because the students are able and allowed to play the online games whenever they want and need without any schedule set. They will still be able to access the game even after they graduate from the university, for instance. 
JEASP

Journal of English for Academic and Specific Purposes

Volume 4 Number 1, June, 2021

\section{CONCLUSION}

Referring to the findings that have been formerly presented, several conclusions can be made. In order to help the students to develop themselves to be effective readers who are capable of monitoring their understanding and using a reading strategy properly, online reading games are one of the great preferences for online teaching and learning activities. These have helped the students to visualize the situation or context of the particular texts given in the games better because of its animation and sound effects. These online games have made the students realized that it is important to be a good reader. In regard to this, increasing accuracy in reading is critical to figure out the writers' messages. They have also become more active in engaging themselves in the class discussion after having several experiences of playing the online reading games, which can also be executed at the most convenient time for them. It has proven that studying while playing is an effective learning strategy for the majority of the students.

Moreover, if educators want to implement the student-centered learning approach in their class, they need to refrain themselves from giving too many commands to the students and ask them to study particular topics without considering their voices. Having the authority to choose what they want to study through the online reading games and play the games by themselves at any time means that the students are, indeed, engaged in an active rather than a passive learning. This activity may also lead to a lifelong learning process.

Elicited from the conclusion of the findings and discussion, there surely is limitation in this study. For the teachers focusing their lesson on reading skill, they are able to practice the similar approach used in this research. However, there are three suggestions from the recent researchers; first, it will be better if teachers can set the adequate time allocation for both lecturing and game sessions. By balancing the two sessions, it is expected that students can fully experience the meaningful as well as the life-long learning. Second, besides the game introduced in this study, teachers can also explore more online games regarding reading skill provided in several learning-purpose websites. Lastly, teachers should also consider easy access since not all students live in a place with strong internet signals. Before deciding to use it for students' learning experience, teachers must test it first to know whether it is accessible for everyone. In addition, it will be better if the future researchers who are also concerned in studying the media for foreign language learning study can introduce a different media for other language skills i.e. speaking, listening, and writing. Not only do the future researchers may utilize the already existing media such as online games in several websites, they are more than welcomed to create their own online media for learning foreign language. The media they created in the future will improve the quality of English Language Teaching in Indonesia.

\section{REFERENCES}

Bakhsh, S. A. (2016). Using Games as a Tool in Teaching Vocabulary to Young Learners. English Language Teaching, 9 (7), 120-128. DOI: $10.5539 /$ elt.v9n7p120

Brown, H. D. \& Lee, H. (2015). Teaching by Principles: An Interactive Approach to Language Pedagogy (4th Edition). New York: Pearson Education. 


\section{JEASP}

Journal of English for Academic and Specific Purposes

Volume 4 Number 1, June, 2021

Cam, L. \& Tran, T. M. T. (2017). An Evaluation of Using Games in Teaching English Grammar for First Year English-Majored Students at Dong Nai Technology University. International Journal of Learning, Teaching and Educational Research, 16 (7), 55-71.

Corti, Kevin. (2006). Games--Based Learning; A Serious Business Application. PIXELearning Limited.

Evandio, A. (2020). "Penggunaan Aplikasi Video Conference di Indonesia, Zoom Pemenangnya?". www.bisnis.com/teknologi (October 12, 2020).

Jeon, S. A. S. (2014). The Impact of Playing Commercial Online Games on Young Korean EFL Learners' L2 Identity. In: Rich S. (eds) International Perspectives on Teaching English to Young Learners: International Perspectives on English Language Teaching. London: Palgrave Macmillan. DOI: 10.1057/9781137023230_5

Kassop, M. (2003). Ten Ways Online Education Matches, or Surpasses, Face-to-Face Learning. The Technology Source Archives. from http://backbonecommuni- cations.com/news/ten-ways-online-education-matchesor-surpasses-face-to-face-learning/ (October 21, 2020).

Kasvi, J. (2000). Not Just Fun and Games_-Internet Games as a Training Medium. In P. Kymäläinen \& L. C. Seppänen (Eds.), Cosiga_Learning with Computerised Simulation Games. Helsinki, Skidoo.

Kirszner, Laurie G., \& Mandell, Stephen R. (2009). Writing First with Reading: Practice in Contexts. New York: Bedford/St. Martin's.

Kearney, P., \& Pivec, M. (2007). Games for Learning and Learning from Games. Informatica, 31, 419-423.

Lawrence, A. J. \& Lawrence, A. S. A. (2013). Attitude of Student Teachers towards Using Grammar Games for Teaching English. International Journal on New Trends in Education and Their Implications, 4 (1), 65-72.

Lea, S. J., Stephenson, D., \& Troy, J. (2003). Higher Education Students' Attitudes to Student Centered Learning: Beyond 'Educational Bulimia'. Studies in Higher Education, 28 (3), 321-334.

Liu, P. L. (2016). Mobile English Vocabulary Learning Based on Concept-Mapping Strategy. Language Learning \& Technology, 20 (1), 128-140.

Norman, D. (1993). Things that Make Us Smarter: Defending Human Attributes in the Age of the Machine. New York: Addison -Wesley.

Orey, Michael. (2010). Emerging Perspectives on Learning, Teaching, and Technology. Zurich: The Jacobs Foundation.

O’Neill, G. \& McMahon, T. (2005). Student-Centred Learning: What does It Mean for Students and Lecturers? In: O’Neill, G., Moore, S., \& McMullin, B. (Eds) Emerging Issues in the Practice of University Learning and Teaching. Dublin: AISHE.

Palmer, C. \& Bolderston, A. (2006). A Brief Introduction to Qualitative Research. The Canadian Journal of Medical Radiation Technology / CAMRT, 37 (1), 16-19.

Patil, V. (2014). Technologies Used In E-learning. Scholarly Research Journal for Humanity Science \& English Language, 1 (2), 280 - 285.

Sanchez, M.M.M., Morfin, A.P., \& Campos, V.E.P. (2007). Interactive Games in the Teaching-Learning Process of A Foreign Language. Teoria Y Praxis, 4, 47 - 66.

Schrum, L., \& Hong, S. (2002). Dimensions and strategies for online success: Voices from experienced educators. Journal of Asynchronous Learning Networks, 6(1), 57-67.

TEAL Center. (2010). Student-Centered Learning. American Institute for Research, 6, 1-3. 


\section{JEASP}

Journal of English for Academic and Specific Purposes

Volume 4 Number 1, June, 2021

Tuan, L. T. \& Doan, N. T. M. (2010). Teaching English Grammar through Games. Studies in Literature and Language, 1 (7), 61-75.

Vasileiadou, I., \& Marina, Z. (2017). Using Online Games Computer in the ELT Classroom: A Case Study. Canadian Center of Science and Education, English Language Teaching, 10 (12), 134-150.

Wang, Y. (2010). Using Communicative Language Games in Teaching and Learning English in Taiwanese Primary Schools. Journal of Engineering Technology and Education, 7 (1), 126-142.

Wigfield, A., \& Guthrie, J. T. (1997). Relations of Children's Motivation for Reading to the Amount and Breadth of Their Reading. Journal of Educational Psychology, 89 (3), 420-432.

Yip, F. W. M. \& Kwan, A. C. M. (2006). Online Vocabulary Games as a Tool for Teaching and Learning English Vocabulary. Educational Media International, 43 (3), 233-249. DOI: 10.1080/09523980600641445

Yolageldili, G. \& Arikan, A. (2011). Effectiveness of Using Games in Teaching Grammar to Young Learners. Elementary Education Online, 10 (1), 219-229.

Zirawaga, V. S., Olusanya, A.I, \& Maduku, T. (2017). Gaming in Education: Using Games as A Support Tool to Teach History. Journal of Education and Practice, 8 (15), 55-64. 